\title{
Response of Caper Plant to Drought and Different Ratios of Calcium and Sodium Chloride ${ }^{1}$
}

\author{
Resposta da Planta de Alcaparra à Seca e Diferentes Proporções de Cloreto de Cálcio e Cloreto \\ de Sódio
}

ROSTAMI, L. ${ }^{2}$, SADEGHI, $\mathrm{H} .^{2}$, and HOSSEINI, S. ${ }^{2}$

\begin{abstract}
Caper (Capparis spinosa) is used as multipurpose and adaptable plant which provides a valuable opportunity to enhance greenery in harsh climatic areas. This plant like the others is affected by drought and sodium chloride stresses as the most common abiotic stresses worldwide. This study was carried out to determine the interaction between drought and different ratios of sodium and calcium chloride on caper. Droughts stress were two levels of 100 and $75 \%$ of field capacity and were applied based on the daily weighting method of pots. Salt treatments were four different ratios of calcium chloride: sodium chloride $(1: 0$, $1: 1,1: 3,1: 5]$. Treatments started when the plants were sown in the pots. Results indicated that higher ratios of calcium chloride than sodium chloride which caused salinity stress have destructive effect on water relationships and contents of the caper. This stress affected growth, morphological, and physiological function related traits in a negative way. Growth and other traits decreased under water deficit conditions. It seems that interaction between salinity and drought had the most destructive effect on this plant and decreasing its quality and quantity of its traits.
\end{abstract}

Keywords: salt stress, chlorophyll index, water content.

RESUMO - A alcaparra (Capparis spinosa) é utilizada como planta multifuncional e adaptável que fornece uma oportunidade valiosa de melhoramento de vegetais em áreas climáticas adversas. Essa planta, como as outras, é afetada pelos estresses hidrico e do cloreto de sódio, que são os estresses abióticos mais comuns no mundo. Este estudo foi realizado para determinar a interação entre a seca $e$ as diferentes proporções de cloreto de cálcio e cloreto de sódio na alcaparra. O estresse hídrico estava em dois niveis (100 e 75\% da capacidade de campo) e foi aplicado com base no método de pesagem diária de recipientes. Os tratamentos salinos estavam com quatro proporções diferentes de cloreto de cálcio: cloreto de sódio (1:0, 1:1, 1:3 e 1:5). Os tratamentos começaram quando as plantas foram semeadas nos recipientes. Os resultados indicaram que maiores proporções de cloreto de cálcio do que de cloreto de sódio, que causaram estresse por salinidade, possuem efeito destrutivo nas relações de água e teor de alcaparra. Este estresse afetou o crescimento e as caracteristicas relacionadas à função morfológica e fisiológica de forma negativa. O crescimento e outras características tiveram redução sob condições de déficit hidrico. Parece que a interação entre a salinidade e a seca teve o efeito mais destrutivo nessa planta, diminuindo sua qualidade e a quantidade de suas caracteristicas.

Palavras-chave: estresse salino, índice de clorofila, teor de água.

\section{INTRODUCTION}

Water deficit or drought stress and salinity caused by sodium chloride are some of the most common abiotic stresses that induce a significant reduction in photosynthesis, which depends on the photosynthesizing tissue and photosynthetic pigments, so that decreases overall growth traits in the plants. Moreover, this stress increases the production of reactive

1 Recebido para publicação em 30.10.2015 e aprovado em 5.1.2016.

2 Department of Natural Resources and Environmental Engineering, College of Agriculture, Shiraz University, Shiraz, Iran. <sadeghih@shirazu.ac.ir>. 
oxygen species (ROS), including superoxide radical $\left(\mathrm{O}_{2}^{-}\right)$, hydrogen peroxide $\left(\mathrm{H}_{2} \mathrm{O}_{2}\right)$, hydroxyl radical $\left(\mathrm{OH}^{-}\right)$and singlet oxygen $\left(\mathrm{O}^{-}\right)$. The adaptability of plant species to water deficit condition concentrations in soil can be managed by accumulation of osmotic solutes, and higher activity of the plant's antioxidant system (Saed-Moucheshi et al., 2014). Many researchers have reported higher activity of enzymatic antioxidant under this environmental stress and other environmental stresses (Ahmadi \& Ardekani, 2006; Aliasgharzadeh et al., 2001; Parida \& Das, 2005). Salt stress is caused simply by occurrence of metabolic disorders due to deterioration of moisture content in the soil or due to excessive accumulation of $\mathrm{Na}^{+}$and $\mathrm{Cl}^{\prime}$ in plants (Lee et al., 2014). Chemical treatment and agronomical crop management practices have been tried to alleviate the water deficit effects, but the application of $\mathrm{CaCl}_{2}$ to stressed plants have attracted little attention (Jaleel et al., 2007). One possible approach to reduce the effect of water deficit on plant productivity is through the addition of calcium supplements to irrigation water (Manivannan et al., 2007). Supplementing the medium with $\mathrm{Ca}^{2+}$ alleviates growth inhibition by salt in glycophyte plants (Yan et al., 1992). $\mathrm{Ca}^{2+}$ sustains $\mathrm{K}^{+}$transport and $\mathrm{K}^{+} / \mathrm{Na}^{+}$selectivity in $\mathrm{Na}^{+}$challenged plants. The interaction of $\mathrm{Na}^{+}$and $\mathrm{Ca}^{2+}$ on plant growth and ion relations is well established (Rengel, 1992).

Caper plant (Capparis spinosa), a multipurpose plant, requires a semi-arid or arid climate (Legua et al., 2013). This plant is used as a multipurpose and adaptable plant which provides a valuable opportunity to enhance greenery in harsh climatic areas. The erosion of the soil is a great problem in these climatic conditions. Moreover, this plant has a deep root system and is resistant to drought condition, and it can tolerate temperatures exceeding $40{ }^{\circ} \mathrm{C}$ (Suleiman et al., 2012). Caper plant can cover soil surfaces with its vegetative canopy and reserve soil water (Shafiq et al., 2015). Furthermore, it could be used for culinary and medicinal purposes, as well as for ornamental shrub. Caper plant as a shrub is well adapted to water deficit conditions having less than $200 \mathrm{~mm}$ annual rainfall, but for commercial uses and plant production this crop cannot be grown under such conditions without any irrigation (Legua et al., 2013).

Considering the importance of the caper, its different consumption in human activities and industry, as well as its significant resistance to salinity and drought stresses worldwide, this study was carried out to evaluate the interaction between different calcium chloride and sodium chloride ratios and water deficit stress on this plant.

\section{MATERIAL AND METHODS}

\section{Experimental procedure}

The experiment was conducted as factorial, with two factors of drought and salinity levels arranged in a completely randomized blocks design with five replications. The pots were kept out of the glasshouse in natural conditions in 2014-2015. Drought stress was two levels of 100 and $75 \%$ of field capacity and was applied according to daily weighting method of pots.

For the determination of field capacity, pots with dry soil were weighed, soaked, and, after total drain of the water, weighed again. The maximum water holding capacity (approximately 20\%) was determined by the difference between dry and soaked soil weights. The determination of water refill for all field capacity was calculated in relation to this difference. To maintain the soil close to the field capacity in the different water regimes, all pots were weighed and adjusted every two days. During this initial growth phase, seedlings were kept close to field capacity, with different water regimes applied after 70 days.

Four ratios of calcium chloride: sodium chloride $(1: 0,1: 1,1: 3,1: 5)$ were also applied. Treatments started when plants were sown in pots.

\section{Measurement of the traits}

Forty days after sowing, plant samples were cut and used to measure relative water content (RWC), water saturation deficit (WSD), shoot moisture percentage, and chlorophyll content. Morphological traits consisting of the 
number of leaves per plant, leaf length, shoot length and root length were recorded.

\section{Statistical analysis}

A univariate normality test was carried out on residuals of the ANOVA model for all traits to test the hypothesis of normal distribution of data by using the statistical software SAS Program Version 9.1.3 (2003) (SAS Institute Inc., Cary, NC, USA). The main effects of factors and their interactions were tested using variance analysis (ANOVA) by GLM procedure of SAS. The Least significant difference (LSD) was used for mean comparison of treatments at the significant level of $5 \%$.

\section{RESULTS AND DISCUSSION}

\section{The effect of treatments on water relationships parameters}

There was a significant difference between 100 and $75 \%$ field capacity for RWC, and $100 \% \mathrm{FC}$ was higher for the root and leaves (Figure 1). RWC was lower with increased ratio of sodium chloride under $100 \% \mathrm{FC}$ and decreased with higher ratio under $75 \% \mathrm{FC}$ in both root and leaves. The Highest and lowest RWC were found with ratios of $1: 0$ and $1: 5$ under $100 \% \mathrm{FC}$ for both root and leaves, respectively. The rate of decrease in RWC in line with increase sodium chloride ratio was higher under $100 \%$, compared to $75 \%$ FC.

The higher ratio of sodium chloride decreased WSD (water saturation deficit) in both root and leaves under 100 and $75 \%$ FC (Figure 2) and the Highest WSD were obtained in $1: 5$ ratios under $75 \% \mathrm{FC}$, while the lowest ones were achieved in 1:0 ratio. WSD was generally lower than $100 \% \mathrm{FC}$ under $75 \% \mathrm{FC}$. WSD was higher in the root, compared to leaves.

Higher ratio of sodium chloride reduced shoot moisture content and the highest shoot moisture percentage was obtained in the ratio of $1: 0$ under $100 \% \mathrm{FC}$ with no significant difference from the same ratio under $75 \% \mathrm{FC}$ (Table 2). The lowest one was recorded in the ratio of $1: 5$ under $75 \% \mathrm{FC}$. Water stress also decreased the shoot moisture percentage.

\section{The effect of treatment on chlorophyll content}

Chlorophyll index was measured using SPAD which represents chlorophyll content of leaves. These indexes were generally lower in 100 than in $75 \%$ FC (Figure 3). Under both FC conditions $(100 \%$ and $75 \%)$ the ratio of $1: 0$ showed higher chlorophyll content than other

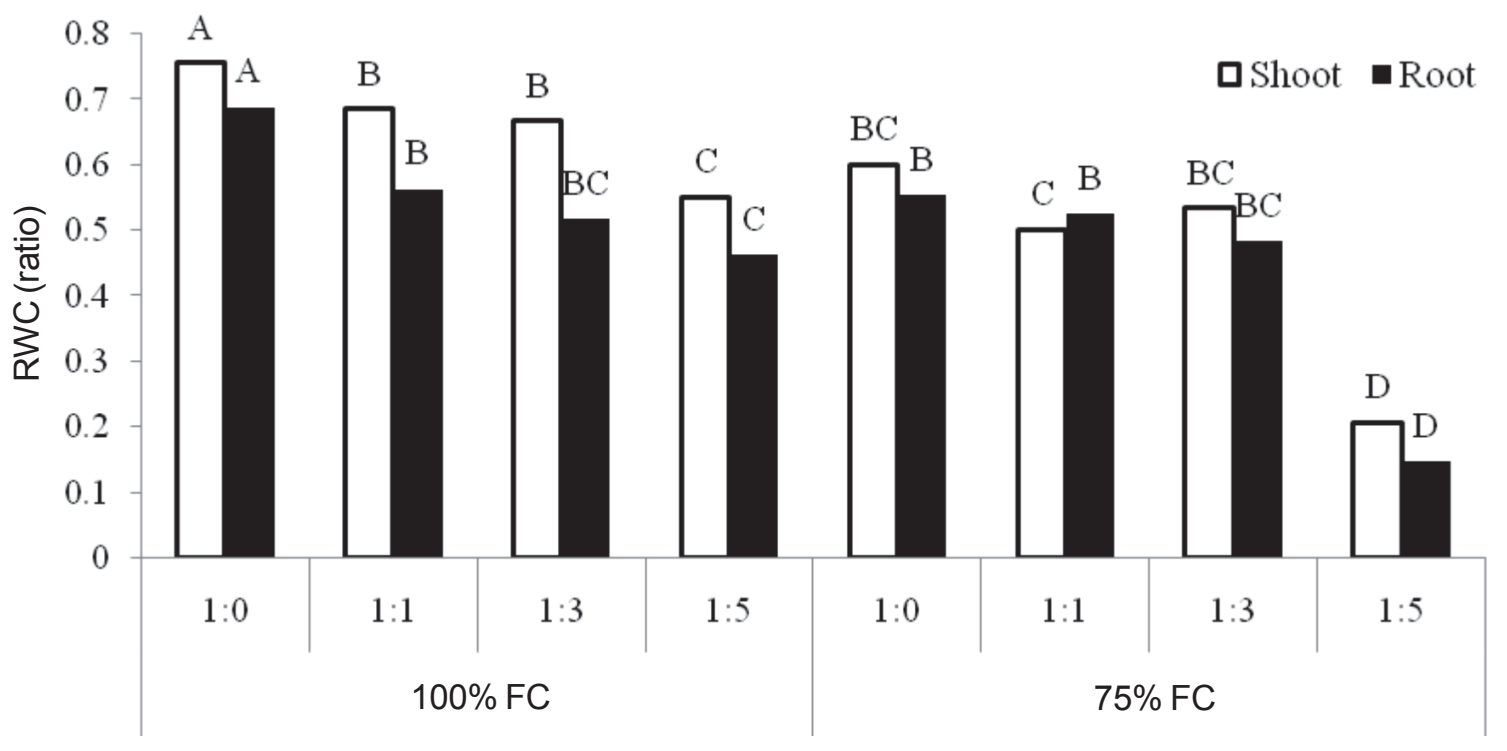

Figure 1 - Relative water content of leaf and root of caper in drought and different ratios of calcium and sodium chloride. 


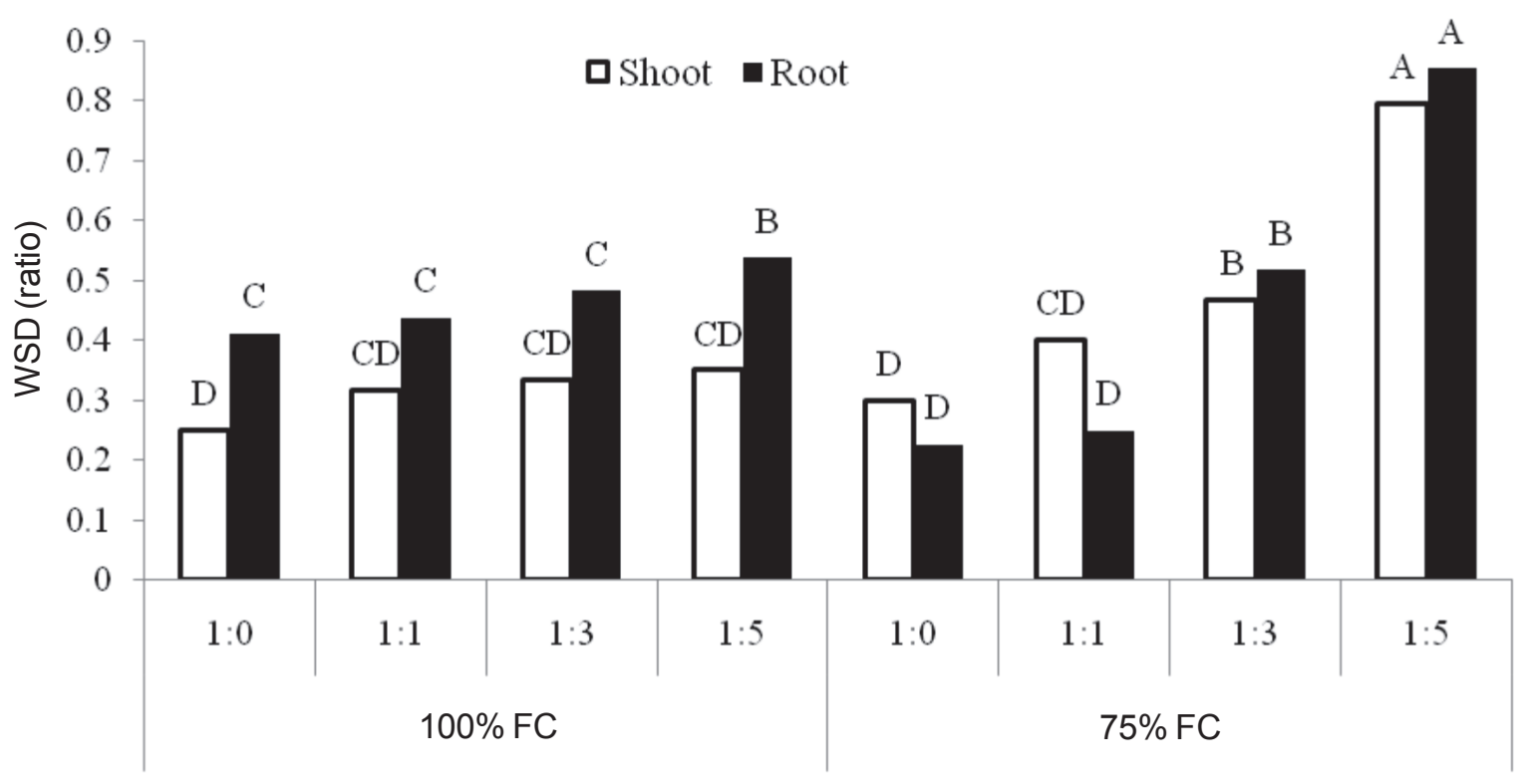

Figure 2 - Water saturated deficit measured for leaf and root of Caper in drought and different ratios of calcium and sodium chloride.

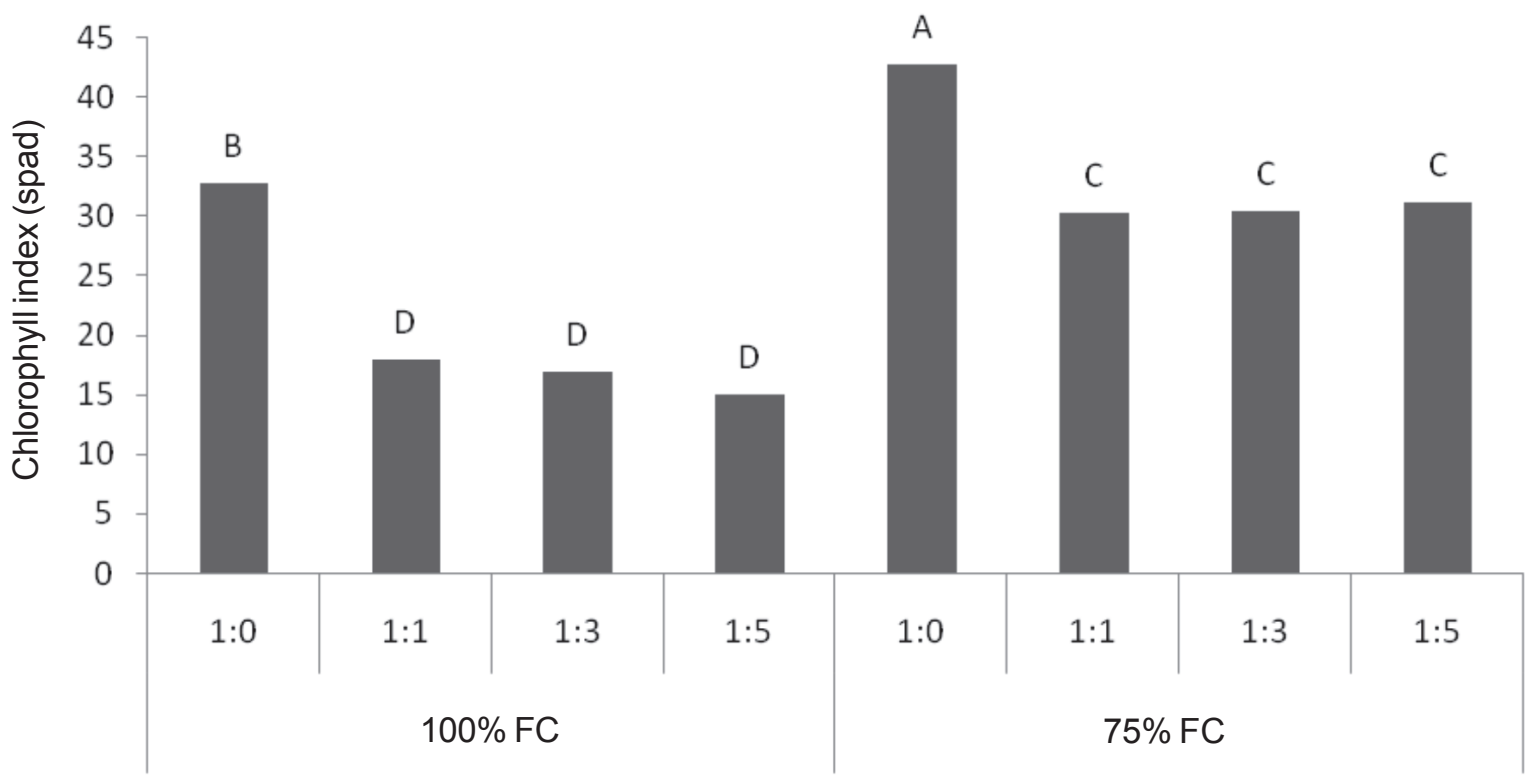

Figure 3 - Chlorophyll index in different treatments for Caper in drought and different ratios of calcium and sodium chloride.

ratios with no significant difference from other ratios.

The effect of treatments on morphological and plant related parameters

Shoot and root fresh and dry weight were measured as caper plant components. Drought stress significantly decreased all plant components, the highest being found in the ratio of 1:0 of calcium chloride: sodium chloride under $100 \% \mathrm{FC}$ with no significant difference from the same ratio under $75 \%$ FC related to shoot fresh weight and dry weight (Table 1). The lowest yield components traits were obtained in ratio $1: 5$ under $75 \%$ FC. 
Morphological traits including plant height, number of leaves per plant, leaf length, first node length, and root length were measured in the capper plants. Except for the root length, higher ratios of calcium chloride decreased other traits compared to sodium chloride (Table 2). The highest plant height, number of leaves per plant, leaf length, and first node length were obtained in ratio 1:0 under 100\% with no significant difference from the similar ratio under $75 \% \mathrm{FC}$ for plant height, number of leaves per plant, and leaf length. The lowest values for plant height, number of leaves per plant, leaf length, and first node length were recorded at the highest ratio $(1: 5)$ of calcium chloride: sodium chloride fewer than $75 \% \mathrm{FC}$. In all morphological traits $100 \% \mathrm{FC}$ had higher values. Root length increased with higher ratio of sodium chloride, and the highest and lowest root length were found in 1:5 and
1:0 ratios under both 75 and $100 \% \mathrm{FCs}$, respectively.

The results of water relationship related traits including RWC, WSD, and shoot and root moisture percentage showed that water deficit conditions reduced the water content traits in root and leaves. Higher concentration of sodium chloride reduced RWC and shoot moisture percentage, while the WSD was increased. The ratio of 1:0 didn't show significant difference in some cases under $100 \% \mathrm{FC}$ and $75 \% \mathrm{FC}$. Water stress is characterized by reduction of water content, turgor, total water potential, wilting, closure of stomata and decrease in cell enlargement and growth (Sadeghi \& Robati, 2015). Higher sodium chloride concentration caused salinity stress in plants. Because salinity affects osmotic potential in the plant cells, it is

Table 1 - Mean comparison for shoot and root measured traits

\begin{tabular}{|c|c|c|c|c|c|c|}
\hline \multirow{2}{*}{ Drought } & Ratio & $\begin{array}{c}\text { Shoot fresh } \\
\text { weight } \\
(\mathrm{gr})\end{array}$ & $\begin{array}{c}\text { Shoot dry weight } \\
(\mathrm{gr})\end{array}$ & $\begin{array}{c}\text { Shoot moisture } \\
\text { percent (\%) }\end{array}$ & $\begin{array}{c}\text { Root fresh } \\
\text { weight (gr) }\end{array}$ & $\begin{array}{c}\text { Root dry weight } \\
(\mathrm{gr})\end{array}$ \\
\hline \multirow{5}{*}{$100 \% \mathrm{FC}$} & $1: 0$ & $0.90 \mathrm{~A}$ & $0.30 \mathrm{AB}$ & $80.00 \mathrm{AB}$ & $0.60 \mathrm{BC}$ & $0.25 \mathrm{~B}$ \\
\cline { 2 - 7 } & $1: 1$ & $0.70 \mathrm{AB}$ & $0.26 \mathrm{BC}$ & $72.22 \mathrm{C}$ & $0.45 \mathrm{DE}$ & $0.17 \mathrm{C}$ \\
\cline { 2 - 7 } & $1: 3$ & $0.50 \mathrm{CD}$ & $0.20 \mathrm{C}$ & $71.43 \mathrm{C}$ & $0.40 \mathrm{E}$ & $0.13 \mathrm{D}$ \\
\cline { 2 - 7 } & $1: 5$ & $0.40 \mathrm{D}$ & $0.20 \mathrm{C}$ & $69.23 \mathrm{D}$ & $0.30 \mathrm{~F}$ & $0.10 \mathrm{D}$ \\
\hline \multirow{3}{*}{$75 \% \mathrm{FC}$} & $1: 0$ & $0.90 \mathrm{~A}$ & $0.37 \mathrm{~A}$ & $81.25 \mathrm{~A}$ & $0.75 \mathrm{~A}$ & $0.30 \mathrm{~A}$ \\
\cline { 2 - 7 } & $1: 1$ & $0.80 \mathrm{AB}$ & $0.31 \mathrm{~B}$ & $78.57 \mathrm{~B}$ & $0.60 \mathrm{BC}$ & $0.25 \mathrm{~B}$ \\
\cline { 2 - 7 } & $1: 3$ & $0.70 \mathrm{AB}$ & $0.27 \mathrm{~B}$ & $77.78 \mathrm{~B}$ & $0.55 \mathrm{C}$ & $0.18 \mathrm{C}$ \\
\cline { 2 - 7 } & $1: 5$ & $0.65 \mathrm{BC}$ & $0.22 \mathrm{C}$ & $77.78 \mathrm{~B}$ & $0.50 \mathrm{CD}$ & $0.13 \mathrm{D}$ \\
\hline
\end{tabular}

Means with the similar letters in each column are not significantly different (LSD 5\%).

Table 2 - Mean comparison for morphological measured traits

\begin{tabular}{|c|c|c|c|c|c|c|}
\hline Drought & Ratio & $\begin{array}{c}\text { Plant height } \\
(\mathrm{cm})\end{array}$ & Leaf number & $\begin{array}{c}\text { Leaf length } \\
(\mathrm{cm})\end{array}$ & $\begin{array}{c}\text { First nod length } \\
(\mathrm{cm})\end{array}$ & $\begin{array}{c}\text { Root length } \\
(\mathrm{cm})\end{array}$ \\
\hline \multirow{5}{*}{$100 \% \mathrm{FC}$} & $1: 0$ & $20.67 \mathrm{~A}$ & $11.3 \mathrm{~A}$ & $4.00 \mathrm{~A}$ & $2.17 \mathrm{~A}$ & $12.00 \mathrm{CD}$ \\
\cline { 2 - 7 } & $1: 1$ & $17.66 \mathrm{~B}$ & $9.30 \mathrm{AB}$ & $3.50 \mathrm{~B}$ & $1.33 \mathrm{~B}$ & $13.67 \mathrm{BC}$ \\
\cline { 2 - 7 } & $1: 3$ & $14.00 \mathrm{C}$ & $8.67 \mathrm{~B}$ & $3.40 \mathrm{~B}$ & $1.13 \mathrm{~B}$ & $18.33 \mathrm{~A}$ \\
\cline { 2 - 7 } & $1: 5$ & $13.66 \mathrm{CD}$ & $6.67 \mathrm{C}$ & $3.23 \mathrm{BC}$ & $0.73 \mathrm{CD}$ & $18.33 \mathrm{~A}$ \\
\hline \multirow{3}{*}{$75 \% \mathrm{FC}$} & $1: 0$ & $19.67 \mathrm{~A}$ & $11.00 \mathrm{~A}$ & $3.80 \mathrm{~A}$ & $1.17 \mathrm{~B}$ & $11.67 \mathrm{D}$ \\
\cline { 2 - 7 } & $1: 1$ & $14.33 \mathrm{C}$ & $8.00 \mathrm{~B}$ & $3.47 \mathrm{~B}$ & $0.90 \mathrm{BC}$ & $14.67 \mathrm{~B}$ \\
\cline { 2 - 7 } & $1: 3$ & $12.16 \mathrm{DE}$ & $7.00 \mathrm{BC}$ & $3.10 \mathrm{CD}$ & $0.50 \mathrm{D}$ & $14.33 \mathrm{~B}$ \\
\cline { 2 - 7 } & $1: 5$ & $11.50 \mathrm{E}$ & $6.00 \mathrm{C}$ & $2.90 \mathrm{D}$ & $0.47 \mathrm{D}$ & $14.67 \mathrm{~B}$ \\
\hline
\end{tabular}

Means with the similar letters in each column are not significantly different (LSD 5\%). 
indirectly related to drought and oxidative stress (Rodrýguez et al., 2005). Also, drought stress decreased water potential and water contet of plant's tissues and caused plant senescence. In this study, water content traits decreased under both drought and salinity created by higher sodium chloride concentration. .

The chlorphyll index decreased under higher sodium chloride concentration conditions compared to control, which could be related to suppressing effect of its production in plants. The supression of the biosynthesis of the pigments probably resulted from suppressing delta aminolevulinic acid and protochlorophyllide reductase. Higher sodium concentration under salinity conditions reduces absorption of magnesium; since magnesium is the key element for chlorophyll biosynthesis in plants, its content will be reduced.(Parida \& Das, 2005).

Higher morphological traits, such as plant height, number of leaves per plant, leaf length, and first node length for un-stressed plants were higher than for stressed ones. Salinity and drought reduced all these traits. On the other hand, the root length was increased by higher salinity indicating that the plant in this situation is trying to find more potential water to absorb from soil by enlraging its root. Still, root fresh and dry weight were decreased by salinity, showing its distructing effect on the root. However, this stress forced the plant to spend more energy on root length (Pirasteh Anosheh et al., 2011). Root length also decreased under drought stress compared to control conditions. Similar results were obtained under salinity conditions by Meloni et al. (2001) in cotton (Gossypium hirsutum) and Faghire et al. (2013) in common bean (Phaseolus vulgaris)

Yield related traits such as shoot fresh and dry weights were affected by both salinity and drought stress. Salinity stress increases ethylene levels in the plants, which reduces the growth of root and shoot (Evelin et al., 2009).The quality and amount of plant growth depends on cell division, enlargement and differentiation, which are affected by water stress (Doorenbos \& Kassam, 1979). Growth is influenced by various internal and external factors besides its genetical makeup and is an important tool for assessing crop productivity in various crops (Champolivier \& Merrien, 1996). Root characteristics, especially length, length density and the number of thick roots, are important for a plant to have relatively well established above grounded parts by exploiting the available water (Giménez, 2014). A root system that enhances the ability of a plant to capture water, as well as a significantly reduced leaf area under water stress, is a fundamental adaptation mechanism to drought (Sun et al., 2014). This reduction occurred before stomatal conductance reduced the remaining viable leaf area (Ottman \& Kimball, 2012). Reduction in the leaf area by water stress is an important reason for reduced crop yield through reduction in photosynthesis (Chu \& Jiang, 2013). Leaf water potential, osmotic potential and relative water content decreased in stressed plants at all growth stages. The decrease in osmotic potential in response to water deficit was greaterwhen compared to the leaf water potential at all growth stages, indicating the ability of the leaves to maintain turgor through osmotic adjustment (Slattery et al., 2013). The number of leaves per plant, individual leaf size and leaf longevity were reduced by drought. The root growthinitially increased, but reduced at a later stage because of severe drought stress. The reduction in plant height might be associated with reduced cell enlargement and growth due to low turgor pressure and more leaf senescence under drought stress (Fereres et al., 2014).The fresh weight decreased under drought conditions in wheat (Triticum aestivum) (Abdoli et al., 2013; Cui et al., 2015). Similar results have been reported in pearl millet (Pennisetum glaucum) (Kusaka et al., 2005) and Abelmoschus esculentum (Bhatt \& Srinivasa Rao, 2005). The decrease of fresh weight under drought conditions might be the reason for suppression of cell expansion and growth due to the low turgor pressure. The decrease in the total dry weight may be due to the considerable decrease in plant growth, photosynthesis and canopy structure, as indicated by leaf senescence during drought stress in Asteriscus maritimus plants (Rodrýguez et al., 2005). On the other hand, Matsuda \& Riazi (1981) stated generally that the first symptoms of 
salt stress in the plants is a restriction for leaf expansion.

Overall, the results indicated that a higher ratio of sodium chloride than calcium chloride created salinity stress and has a destructive effect on water relationships and contents of the caper plant. This stress affected the growth, morphological, and yield related traits of this plant in a negative way. Growth and other traits decreased under water deficit conditions too. It seems that the interaction between salinity and drought had the most destructive effect on this plant, reducing the quality and quantity of the traits.

\section{ACKNOWLEDGMENTS}

We would like to express our special thanks to the Department of Natural Resources and Environmental engineering, College of Agriculture, Shiraz University for the financial support for this research.

\section{LITERATURE CITED}

ABDOLI, A. et al. Effect of post-anthesis water deficiency on storage capacity and contribution of stem reserves to the growing grains of wheat cultivars. Plant Knowledge J., v. 2, n. 1, p. 99-107, 2013.

AHMADI, S. H.; ARDEKANI, J. N. The effect of water salinity on growth and physiological stages of eight Canola (Brassica napus) cultivars. Irrig. Sci., v.25, n. 1, p.11-20, 2006.

ALIASGHARZADEH, N. et al. Occurrence of arbuscular mycorrhizal fungi in saline soils of the Tabriz Plain of Iran in relation to some physical and chemical properties of soil. Mycorrhiza, v. 11, n. 3, p. 119-122, 2001.

BHATT, R.; SRINIVASA RAO, N. Influence of pod load on response of okra to water stress. Indian J.Plant Physiol., v. 10, n. 1, p. 54-59, 2005.

CHAMPOLIVIER, L.; MERRIEN, A. Effects of water stress applied at different growth stages to Brassica napus L. var. oleifera on yield, yield components and seed quality. Eur J Agron, v. 5, n. 1, p. 153-160, 1996.

CHU, L.; JIANG, N. Study on compensation effects of nitrogen and water stress duration in the yield of soybean. In: INTERNATIONAL CONFERENCE ON NEW TECHNOLOGY OF AGRICULTURAL ENGINEERING, 2011.. Proceedings... 2013. v. 84. p. 189-193.
CUI, Y. et al. Effect of water deficit during vegetative growth periods on post-anthesis photosynthetic capacity and grain yield in winter wheat (Triticum aestivum L.). Acta Physiol. Planta., v. 37, n. 1, p. 1-10, 2015.

DOORENBOS, J.; KASSAM, A. Yield response to water. Irrig. Drainage Paper, v. 33, n. 1, p. 257, 1979.

EVELIN, H. et al. Arbuscular mycorrhizal fungi in alleviation of salt stress: a review. Ann. Bot., v. 104, n. 7, p. 1263-1280, 2009.

FAGHIRE, M. et al. Genotypic variation of nodules' enzymatic activities in symbiotic nitrogen fixation among common bean (Phaseolus vulgaris L.) genotypes grown under salinity constraint. Symbiosis, v. 60, n. 3, p. 115-122, 2013.

FERERES, E. et al. Balancing crop yield and water productivity trade offs in herbaceous and woody crops. Func. Plant Biol., v. 41, n. 11, p. 1009-1018, 2014.

GIMÉNEZ, L. Effect of water deficiencies at different stages of development on soybean yield. Agrociencia, v. 18, n. 1, p. 53-64, 2014.

JALEEL, C. A. et al. Water deficit stress mitigation by calcium chloride in Catharanthus roseus: Effects on oxidative stress, proline metabolism and indole alkaloid accumulation. Colloids Surf. B: Biointer., v. 60, n. 1, p. 110-116, 2007.

KUSAKA M. et al. The maintenance of growth and turgor in pearl millet (Pennisetum glaucum [L.] Leeke) cultivars with different root structures and osmo-regulation under drought stress. Plant Sci., v. 168, n. 1, p. 1-14, 2005.

LEE, S. Y. et al. Influence of salicylic acid on rubisco and rubisco activase in tobacco plant grown under sodium chloride in vitro. Saudi. J. Biol. Sci., v. 21, n. 5, p. 417-426, 2014.

LEGUA, P. et al. Phenological growth stages of caper plant (Capparis spinosa L.) according to the Biologische Bundesanstalt, Bundessortenamt and CHemical scale. Ann. Appl. Biol., v. 163, n. 1, p. 135-141, 2013.

MANIVANNAN, P. et al. Growth, biochemical modifications and proline metabolism in Helianthus annuus L. as induced by drought stress. Colloids Surfaces B: Biointerf., v. 59, n. 2, p. 141-149, 2007.

MATSUDA, K., RIAZI, A. Stress-induced osmotic adjustment in growing regions of barley leaves. Plant Physiol., v. 68, n. 3, p. 571-576, 1981.

MELONI, D. A. et al. Contribution of proline and inorganic solutes to osmotic adjustment in cotton under salt stress. J. Plant Nutr., v. 24, n. 3, p. 599-612, 2001. 
OTTMAN, M.; KIMBALL, B. Invinsa application to reduce water stress effects on corn growth and yield at Maricopa, AZ, 2012. Forage and Grain: A College of Agriculture and Life Sciences Report. Tucson: College of Agriculture, University of Arizona, 2011.

PARIDA, A. K.; DAS, A. B. Salt tolerance and salinity effects on plants: a review. Ecotoxicol Environ Safety, v. 60, n. 3, p. 324-349, 2005.

PIRASTEH ANOSHEH, $\mathrm{H}$. et al. Chemical priming with urea and kno3 enhances maize hybrids (Zea mays L.) seed viability under abiotic stress. J. Crop Sci. Biotechnol., v. 14, n. 4, p. 289-295, 2011.

RENGEL, Z. The role of calcium in salt toxicity. Plant Cell Environ., v. 15, n. 1, p. 625-632, 1992.

RODRIGUEZ, P. et al. Effects of $\mathrm{NaCl}$ salinity and water stress on growth and leaf water relations of Asteriscus maritimus plants. Environ. Exper. Bot., v. 53, n. 2, p. 113-123. 2005.

SAS Institute Inc. JMP v. 9.1.3. Cary: 2003.

SAED-MOUCHESHI, A. et al. Reactive oxygen species (ROS) generation and detoxifying in plants. J. Plant Nutr., v. 37 , n. 10 , p. $1573-1585,2014$.
SADEGHI, H.; ROBATI, Z. Response of Cichorium intybus L. to eight seed priming methods under osmotic stress conditions. Biocatal. Agric. Biotechnol., v. 4, n. 3, p. 443-448, 2015.

SHAFIQ, S. et al. Does exogenously-applied trehalose alter oxidative defense system in the edible part of radish (Raphanus sativus L.) under water-deficit conditions? Sci. Hortic., v. 185, n. 1, p. 68-75, 2015.

SLATTERY, R. A. et al. A meta-analysis of responses of canopy photosynthetic conversion efficiency to environmental factors reveals major causes of yield gap. J. Exper. Bot., v. 64, n. 12, p. 3723-3733, 2013.

SULEIMAN, M. K. et al. Effect of Rooting Hormones (IBA and NAA) on Rooting of Semi Hardwood Cuttings of Capparis spinosa. J. Agric. Biod. Res., v. 1, n. 1, p. 135-139, 2012.

SUN, W.H. et al. Effect of water stress on yield and nutrition quality of tomato plant overexpressing StAPX. Biol. Planta. v. 58, n. 1, p. 99-104, 2014.

YAN, F. et al. Effect of low root medium $\mathrm{pH}$ on net proton release, root respiration, and root growth of corn (Zea mays L.) and broad bean (Vicia faba L.). Plant Physiol., v. 99, n. 2, p. 415-421, 1992. 